\title{
INAFASTABILIDADE DA JURISDIÇÃO E AUTOTUTELA: O EXEMPLO DA CLÁUSULA RESOLUTIVA EXPRESSA ${ }^{1}$
}

\section{GUARANTEE OF RECOURSE TO THE COURTS VERSUS SELF-ADMINISTERED JUSTICE: THE EXAMPLE OF THE EXPRESS TERMINATION CLAUSE}

Aline de Miranda Valverde Terra Doutora e Mestre em Direito Civil pela Universidade do Estado do Rio de Janeiro - UERJ. Professora Adjunta de Direito Civil da Faculdade de Direito da UERJ. Professora Permanente do Programa de Pós-Graduação em Direito (Mestrado e Doutorado) da UERJ. Professora de Direito Civil da Pontifícia Universidade Católica do Rio de Janeiro - PUC-Rio. Coordenadora editorial da Revista Brasileira de Direito Civil - RBDCivil. Advogada. Rio de Janeiro/RJ. E-mail: aline@amvt.com.br

\section{Leonardo Faria Schenk}

Doutor e Mestre em Direito Processual pela Universidade do Estado do Rio de Janeiro - UERJ. Professor Adjunto de Direito Processual Civil da Faculdade de Direito da UERJ. Advogado. Rio de Janeiro/RJ. E-mail: leonardo.schenk@pcpcadv.com.br.

RESUMO: O estudo realça a contribuição da cláusula resolutiva expressa para um ambiente negocial mais seguro e previsível, ao permitir que os contratantes preestabeleçam, conjuntamente, em que situações a relação contratual poderá ser resolvida de plano, por meio do exercício legítimo da autotutela, sem que exista a necessidade de prévia atuação do Poder Judiciário.

PALAVRAS-CHAVE: Autotutela. Cláusula Resolutiva Expressa. Requisitos.

1 Artigo recebido em 10/06/2019 e aprovado em 27/08/2019. 
ABSTRACT: The study examines the contribution of the express termination clause to a more secure and predictable business environment, by allowing parties, acting together, to stipulate in advance the situations in which the contractual relationship can be terminated, by means of legitimate exercise of self-administered justice, without the need for previous intervention of the judiciary.

KEY WORDS: Self-administered justice. Express termination clause. Requirements.

SUMÁRIO: Introdução - 1. Inafastabilidade da jurisdição e autotutela - 2. Cláusula resolutiva expressa como instrumento de autotutela - 3. Resolução extrajudicial da relação obrigacional: a secundarização da atuação do poder Judiciário - 4. Conclusão - 5. Referências bibliográficas

\section{Introdução}

Um dos princípios mais caros à ordem democrática brasileira é a inafastabilidade da jurisdição. Previsto no art. $5^{\circ}$, inciso XXXV, da Constituição da República, esse princípio assegura aos jurisdicionados não apenas o acesso formal aos órgãos judiciários, mas também o acesso a uma Justiça que propicie uma efetiva e tempestiva proteção contra qualquer forma de ameaça ou violação a direito, cunhando, assim, o ideário hoje comum de um direito de acesso a uma ordem jurídica justa.

Ensina o professor Paulo Cezar Pinheiro Carneiro que, observada a evolução histórica do acesso à justiça no Brasil, a sociedade, modificada pelas transformações ocorridas em escala mundial a partir do último quarto do século XX, passou a exigir "como inevitável um outro tipo de processo que funcionasse para todos, da forma mais rápida possível, igualitário e equânime e que resultasse em uma sentença eticamente justa”, no lugar de um processo acessível a poucos, caro e demorado, preocupado tão somente com a segurança e a técnica em detrimento dos seus fins. ${ }^{2}$

A sociedade tem exigido um novo desenho da planta jurisdicional, apoiada na constatação, hoje inequívoca, de que a tutela justa e tempestiva dos seus direitos não constitui um monopólio do Poder Judiciário. O fenômeno crescente da desjudicialização eleva entre nós

2 CARNEIRO, Paulo Cezar Pinheiro. Acesso à justiça: juizados especiais cíveis e ação civil pública: uma nova sistematização da teoria geral do processo. 2. ed. rev. atual. Rio de Janeiro: Forense, 2007. p. 48 
Revista Eletrônica de Direito Processual - REDP.

Rio de Janeiro. Ano 13. Volume 20. Número 3. Setembro a Dezembro de 2019

Periódico Quadrimestral da Pós-Graduação Stricto Sensu em Direito Processual da UERJ

Patrono: José Carlos Barbosa Moreira (in mem.). ISSN 1982-7636. pp. 01-19

www.redp.uerj.br

a importância dos instrumentos de autotutela, sem que disso decorra qualquer tipo de violação, a priori, ao princípio da inafastabilidade da jurisdição.

Há, contudo, enorme desconfiança por parte da comunidade jurídica em relação a referidos mecanismos, o que conduz, não raro, ao estabelecimento de diversos embaraços à sua utilização. Ao propósito, a cláusula resolutiva expressa encerra exemplo emblemático do que se afirma.

Constitui a cláusula resolutiva expressa mecanismo de gestão dos riscos contratuais por meio do qual se confere ao contratante não inadimplente o direito potestativo de resolver a relação obrigacional diante do inadimplemento absoluto - sem prejuízo de as partes gerirem outros riscos por meio da cláusula, como se demonstrará. Embora o art. 475 do Código Civil preveja que referida resolução se opera de pleno direito, inúmeras decisões judiciais exigem do credor o ajuizamento de ação. Esse entendimento, ao que parece, não se coaduna com a melhor técnica, e acaba por aniquilar relevante instrumento de autotutela expressamente previsto em lei. É o que se passa a examinar a seguir.

\section{Inafastabilidade da jurisdição e autotutela}

A inafastabilidade da jurisdição, pilar do movimento de acesso à justiça, assegura aos jurisdicionados o acesso a uma Justiça que propicie uma efetiva e tempestiva proteção contra qualquer forma de ameaça ou violação a direito. $\mathrm{O}$ princípio, previsto no art. $5^{\circ}$, inciso XXXV, da Constituição da República, assegura, nas lições de Watanabe, o direito de acesso a uma ordem jurídica justa. ${ }^{3}$

Nesse contexto, Paulo Cezar Pinheiro Carneiro observa que a rapidez deve ser priorizada com o mínimo de sacrifício para a segurança dos julgados, notadamente porque, da exacerbação da segurança não decorre, diretamente, uma maior justiça das decisões. Rapidez e justiça da decisão são valores perfeitamente conciliáveis. Não se pode perder de vista, afirma o professor, que o "maior inimigo da efetividade nos dias de hoje é o tempo". 4

\footnotetext{
3 WATANABE, Kazuo. Tutela antecipada e tutela específica das obrigações de fazer e não fazer (art. 273 e 461 do CPC). In: TEIXEIRA, Sálvio de Figueiredo. Reforma do código de processo civil. São Paulo: Saraiva, 1996. p. 20.

4 CARNEIRO, Paulo Cezar Pinheiro. Acesso à justiça: juizados especiais cíveis e ação civil pública: uma nova sistematização da teoria geral do processo. 2. ed. rev. atual. Rio de Janeiro: Forense, 2007. p. 91-92.
} 
Revista Eletrônica de Direito Processual - REDP.

Rio de Janeiro. Ano 13. Volume 20. Número 3. Setembro a Dezembro de 2019

Periódico Quadrimestral da Pós-Graduação Stricto Sensu em Direito Processual da UERJ

Patrono: José Carlos Barbosa Moreira (in mem.). ISSN 1982-7636. pp. 01-19

www.redp.uerj.br

Não à toa, como destacou Barbosa Moreira, em uma época em que se torna cada vez mais célere, para não dizer vertiginoso, o ritmo das atividades humanas, "assume particular gravidade o problema do tempo necessário à realização do processo”. Ninguém alimenta a ilusória esperança de que se logre construir mecanismos de aplicabilidade geral, capazes de reduzir a uma fração temporal mínima a duração crônica dos processos cíveis. E mesmo que fosse possível, afirma o mestre, o prodígio logo passaria a efêmero. ${ }^{5}$

Também para Greco o direito à prestação jurisdicional em prazo razoável é uma exigência da tutela jurisdicional efetiva, uma vez que a demora no julgamento cria uma instabilidade na situação jurídica das partes, incompatível com a noção de segurança jurídica, valor essencial a toda sociedade democrática. ${ }^{6}$

A exigência de uma tutela efetiva dos direitos, entregue em tempo razoável, tem estimulado, entre nós, o fenômeno da desjudicialização. ${ }^{7}$ Nesse contexto, o princípio da

5 E finaliza o trecho lembrando exemplo conhecido - citado por Neely (Why Courts don't work, Nova York, 1983), porém colhido em Mc Cormick (Canada's Courts, Toronto, 1994), segundo afirma o próprio autor -, que compara a construção do sistema judicial à de uma estrada, de modo que, quanto melhor for a via, maior também será o tráfego, não tardando a aparição dos efeitos perniciosos do desgaste. BARBOSA MOREIRA, José Carlos. Tutela de urgência e efetividade do direito. In: Temas de direito processual, oitava série. São Paulo: Saraiva, 2004. p. 89.

Em outra oportunidade, afirmou o mestre: "Também se lê na Constituição, e desde o seu primeiro momento de vida, que "aos litigantes, em processo judicial ou administrativo, e aos acusados em geral são assegurados o contraditório e a ampla defesa, com os meios e recursos a ela inerentes" (art. $5^{\circ}$, inciso LV). A norma introduzida pela Emenda Constitucional $\mathrm{n}^{\circ} 45$ terá de conviver com essa e não poderá fazer dela tábua rasa. Um processo informado por preocupações garantísticas necessariamente será menos rápido que um processo que as ponha de lado." BARBOSA MOREIRA, José Carlos. O problema da duração dos processos: premissas para uma discussão séria. In: Temas de direito processual, nona série. São Paulo: Saraiva, 2007. p. 377.

6 GRECO, Leonardo. Garantias fundamentais do processo: o processo justo. In: Estudos de direito processual. Campos dos Goytacazes: Ed. Faculdade de Direito de Campos, 2005. p. 269.

7 Em um inventário não exaustivo do fenômeno legislativo da desjudicialização podemos citar: a Lei $\mathrm{n}^{\circ}$ 8.560/1992, que autorizou o reconhecimento da paternidade junto aos serviços de registro civil; a Lei $\mathrm{n}^{\circ}$ 9.514/1997, que regulou os procedimentos de notificação do devedor e o leilão extrajudicial nos contratos de alienação fiduciária; a Lei n ${ }^{\circ}$ 10.931/2004, que autorizou a retificação administrativa dos registros imobiliários; a Lei $\mathrm{n}^{\circ} 11.101 / 2005$, com a criação da recuperação extrajudicial das empresas; a Lei $\mathrm{n}^{\circ} 11.481 / 2007$, que cuidou da regularização fundiária de interesse social em imóveis da União; a Lei ${ }^{\circ} 11.441 / 2007$, que autorizou a lavratura de escritura pública, nos cartórios e tabelionatos, para os casos de inventário, partilha, separação e divórcio; a Lei n. ${ }^{\circ} 11.790 / 2008$, que permitiu o registro das declarações de nascimento feitas após o decurso do prazo legal; a Lei $\mathrm{n}^{\circ} 12.133 / 2009$, que permitiu a habilitação para o casamento perante o oficial do registro civil; a Lei $\mathrm{n}^{\mathrm{o}}$ 13.140/2015, marco da mediação, que regulou o procedimento da mediação extrajudicial, inclusive com a participação da administração pública. Os exemplos seguem com o Código de Processo Civil de 2015 (Lei no 13.105/2015) e com a reforma recente da Lei de Arbitragem (Lei no 9.307/1996).

Exemplos do fenômeno no ordenamento italiano, que têm conduzido o processo judicial de feição ordinária, capaz de assegurar uma ampla e exauriente cognição, pelo caminho da residualidade, podem ser encontrados em: PROTO PISANI, Andrea. Verso la residualità del processo a cognizione piena? In: Studi in onore di Carmine Punzi. Torino: G. Giappichelli Editore, 2008. v. 1, p. 701-707. Para o estudo das técnicas de sumarização da cognição, cf.: SCHENK, Leonardo Faria. Cognição sumária: limites impostos pelo contraditório no processo civil. São Paulo: Saraiva, 2013. 
Revista Eletrônica de Direito Processual - REDP.

Rio de Janeiro. Ano 13. Volume 20. Número 3. Setembro a Dezembro de 2019

Periódico Quadrimestral da Pós-Graduação Stricto Sensu em Direito Processual da UERJ

Patrono: José Carlos Barbosa Moreira (in mem.). ISSN 1982-7636. pp. 01-19

www.redp.uerj.br

inafastabilidade da jurisdição não impede a existência de instrumentos de autotutela no direito brasileiro.

De acordo com Pietro Perlingieri, diversamente da autonomia privada, consistente no poder dos contratantes de regular, por si, seus próprios interesses, a autotutela confere às partes o poder de tutelar, por si, tais interesses. ${ }^{8}$

Identificam-se dois entendimentos divergentes no que tange aos limites da autotutela: sustenta-se, por um lado, que, no ordenamento jurídico contemporâneo, em que se reserva ao Estado o monopólio da força e se proíbe o exercício das próprias razões, a autotutela é excepcional, e admitida apenas quando expressamente prevista em lei, a exemplo do direito de retenção, do desforço possessório, da exceção de inadimplemento, da legítima defesa, da compensação, dentre outros. ${ }^{9}$

Afirma-se, por outro lado, que a autotutela, como expressão da autonomia privada, encerra apenas um dos possíveis modos pelos quais os sujeitos autorregulam seus próprios interesses. Nesse sentido, se ao indivíduo se reconhece o poder de criar normas e estabelecer seus efeitos, a ele deve ser igualmente reconhecido o poder de tutelar o direito emergente daquelas normas por ele ditadas. ${ }^{10}$

Tornar-se-ia possível, assim, admitir a criação, pelos contratantes, de instrumentos de autotutela, inclusive com função resolutiva, não expressamente previstos em lei. Consoante esse entendimento, a ausência de previsão legal de referidos instrumentos pode ser superada adotando-se a "não excepcionalidade da autotutela contratual constitucionalizada", decorrente do "princípio da autonomia privada, devidamente temperado pelos filtros de controle da boa-fé objetiva e da vedação ao abuso". ${ }^{11}$

Sob tal perspectiva, poder-se-ia admitir a resolução extrajudicial do contrato após o transcurso, in albis, do prazo concedido ao contratante inadimplente pelo lesado para

\footnotetext{
${ }^{8}$ PERLINGIERI, Pietro. Manuale di diritto civile. Napoli: ESI, 2005, p. 336.

${ }^{9}$ Nesse mesmo sentido, Pontes de Miranda admite a autotutela apenas nos estritos termos da lei: “A justiça de mão própria somente se permite se, excepcionalmente, o sistema jurídico não a condena; portanto onde se abre exceção ao princípio do monopólio estatal da justiça" (PONTES DE MIRANDA, Francisco Cavalcanti. Tratado de Direito Privado. t. 2, 2. ed. Rio de Janeiro: Editor Borsoi, 1954, p. 324, grifos no original).

${ }^{10}$ SALLES, Raquel Bellini de Oliveira. Autotutela pelo inadimplemento nas relaçóes contratuais. Tese (Doutorado em Direito Civil) - Faculdade de Direito, Universidade do Estado do Rio de Janeiro, Rio de Janeiro, 2011, p. 53-54.

${ }^{11}$ SALLES, Raquel Bellini de Oliveira. Autotutela pelo inadimplemento nas relações contratuais. Tese (Doutorado em Direito Civil) - Faculdade de Direito, Universidade do Estado do Rio de Janeiro, Rio de Janeiro, 2011, p. 212-213.
} 
Revista Eletrônica de Direito Processual - REDP.

Rio de Janeiro. Ano 13. Volume 20. Número 3. Setembro a Dezembro de 2019

Periódico Quadrimestral da Pós-Graduação Stricto Sensu em Direito Processual da UERJ

Patrono: José Carlos Barbosa Moreira (in mem.). ISSN 1982-7636. pp. 01-19

www.redp.uerj.br

adimplir, mediante simples interpelação. ${ }^{12}$ Nesse cenário, estar-se-ia cogitando, em última análise, da aplicação, no Brasil, da diffida ad adempiere, expressamente prevista no art. 1454 do Código Civil italiano, mesmo inexistindo correspondente previsão legal no ordenamento jurídico pátrio. ${ }^{13}$

Ao que parece, dada a excepcionalidade dos instrumentos de autotutela, o primeiro entendimento se afigura mais consentâneo com a ordem jurídica brasileira. No entanto, há de se sublinhar que, se de um lado, apenas hão de ser admitidos mecanismos de autotutela previstos em lei, de outro, devem os operadores do direito garantir sua plena efetividade, sendo-lhes defeso criar embaraços à sua aplicação. A advertência assume particular relevância no âmbito da cláusula resolutiva expressa, cujo viés de autotutela é por vezes obstado pelos Tribunais do país sem fundamento legal, como se demonstrará adiante.

\section{Cláusula resolutiva expressa como instrumento de autotutela}

Produto da autonomia privada dos contratantes, a cláusula resolutiva expressa encerra relevante mecanismo de alocação e disciplina dos riscos contratuais. De regra, afirmase que a cláusula se destina apenas a disciplinar o inadimplemento absoluto. ${ }^{14}$ De fato, o instituto permite às partes distribuir as perdas decorrentes do inadimplemento de obrigações contratuais de forma ímpar, facultando-lhes valorar a relevância de cada obrigação e estabelecer as consequências de sua inexecução, conforme o concreto regulamento de interesses.

\footnotetext{
${ }^{12}$ Nesse sentido, confira-se SALLES, Raquel Bellini de Oliveira. Autotutela pelo inadimplemento nas relações contratuais. Tese (Doutorado em Direito Civil) - Faculdade de Direito, Universidade do Estado do Rio de Janeiro, Rio de Janeiro, 2011, p. 213.

${ }^{13}$ Código Civil italiano, "Art. 1454 Alla parte inadempiente l'altra può intimare per iscritto di adempiere in un congruo termine, con dichiarazione che, decorso inutilmente detto termine, il contratto s'intenderà senz'altro risoluto $(1662,1901)$.

Il termine non può essere inferiore a quindici giorni, salvo diversa pattuizione delle parti o salvo che, per la natura del contratto o secondo gli usi, risulti congruo un termine minore.

Decorso il termine senza che il contratto sia stato adempiuto, questo è risoluto di diritto."

Em tradução livre: “Art. 1.454. À parte faltosa, pode a outra parte intimar, por escrito, à execução, em um prazo razoável, com a declaração de que, decorrido inutilmente o referido prazo, o contrato se considerará, sem mais, como resolvido.

O prazo não pode ser inferior a quinze dias, a não ser acordo diverso das partes ou a não ser que, pela natureza do contrato ou de acordo com os usos, se considere equitativo um prazo menor.

Se decorrer o prazo sem que seja o contrato executado, considerar-se-á este como dissolvido de pleno direito".

${ }^{14}$ Veja-se, por todos: PROENÇA, José Carlos Brandão. A resolução do contrato no direito civil: do enquadramento e do regime. Coimbra: Coimbra Editora, 2006, p. 76.
} 
Revista Eletrônica de Direito Processual - REDP.

Rio de Janeiro. Ano 13. Volume 20. Número 3. Setembro a Dezembro de 2019

Periódico Quadrimestral da Pós-Graduação Stricto Sensu em Direito Processual da UERJ

Patrono: José Carlos Barbosa Moreira (in mem.). ISSN 1982-7636. pp. 01-19

www.redp.uerj.br

A rigor, como aponta Guido Alpa, "anche in queste ipotesi il problema da risolvere

è un problema di distribuizione dei rischi". ${ }^{15} \mathrm{O}$ inadimplemento absoluto é, por si só, um específico risco contratual, a cuja gestão a cláusula resolutiva expressa serve magistralmente. Restringi-la, contudo, à disciplina desse particular risco revela inaceitável misoneísmo. Embora, em sua origem, o instituto estivesse ligado ao inadimplemento absoluto, ${ }^{16}$ sua percepção histórico-relativa impõe a ampliação de seus confins, a permitir a gestão de outros riscos que, uma vez implementados, impeçam a consecução do resultado útil programado.

Desse modo, faculta-se às partes redistribuir os riscos, por exemplo, da superveniência de caso fortuito e força maior, ${ }^{17}$ caracterizados, fundamentalmente, como se depreende do parágrafo único do artigo 393 do Código Civil, ${ }^{18}$ pela inevitabilidade e necessariedade do acontecimento, não já por uma suposta imprevisibilidade. ${ }^{19}$ Para tanto, o risco da impossibilidade causada pelo evento fortuito deve ser assumido pelo devedor, sendo, dessa forma, internalizado ao negócio, como o admite expressamente o caput do artigo 393, em flagrante homenagem à autonomia privada. ${ }^{20}$ Por se tratar de exceção, a assunção do risco deve ser expressa. ${ }^{21}$

Daí a ressalva de Agostinho Alvim, para quem, na dúvida se houve ou não a assunção do risco, "resolve-se em sentido negativo; se se questiona acerca da sua extensão, corta-se a dúvida a favor do devedor". ${ }^{22}$ Imprescindível, ainda, a indicação, um por um, de todos os fatos inevitáveis pelos quais o contratante assume a responsabilidade. ${ }^{23}$ Nesse caso, verificado o

\footnotetext{
${ }^{15}$ ALPA, Guido. Manuale di diritto privato. 8. ed., Padova: CEDAM, 2013, p. 540. Em tradução livre: “mesmo nesses casos, o problema a resolver é um problema de distribuição dos riscos".

${ }^{16}$ IBARGUREN, Carlos. Apuntes de derecho romano: obligaciones. Buenos Aires: Virtus, 1932, p. 349-352.

17 Utilizam-se as expressões como sinônimas, na esteira do entendimento predominante na doutrina nacional. Sobre a identidade dos conceitos, confira-se FONSECA, Arnoldo Medeiros da. Caso fortuito e teoria da imprevisão. 3. ed. Rio de Janeiro: Forense, 1958. p. 129 et seq.

18 “Art. 393. O devedor não responde pelos prejuízos resultantes de caso fortuito ou força maior, se expressamente não se houver por eles responsabilizado. Parágrafo único. O caso fortuito ou de força maior verifica-se no fato necessário, cujos efeitos não eram possível evitar ou impedir".

${ }^{19}$ Nesse sentido: TEPEDINO, Gustavo; BARBOZA, Heloisa Helena; BODIN DE MORAES, Maria Celina. Código Civil interpretado conforme a Constituição da República. 2. ed. rev. e atual. Rio de Janeiro: Renovar, 2007. v. 1. p. 710; PEREIRA, Caio Mário da Silva. Responsabilidade civil. 10. ed. rev. e atual. Rio de Janeiro: GZ, 2012. p. 399. Diversamente: CAVALIERI FILHO, Sérgio. Programa de responsabilidade civil. 6. ed. rev. aum. e atual. São Paulo: Malheiros, 2006. p. 91.

20 TEPEDINO, Gustavo; BARBOZA, Heloisa Helena; BODIN DE MORAES, Maria Celina. Código Civil interpretado conforme a Constituição da República. 2. ed. rev. e atual. Rio de Janeiro: Renovar, 2007. v. 1. p. 712. ${ }^{21}$ Não se admite a assunção tácita do risco relativo à superveniência de caso fortuito e força maior, conforme destaca FONSECA, Arnoldo Medeiros da. Caso fortuito e teoria da imprevisão. 3. ed. Rio de Janeiro: Forense, 1958. p. 180, nota de rodapé n. 8.

${ }^{22}$ ALVIM, Agostinho. Da inexecução das obrigações e suas consequências. São Paulo: Saraiva, 1965. p. 320.

${ }^{23}$ Agostinho Alvim observa que "para que se entenda assumido o risco do caso fortuito extraordinário, é necessário referência expressa" (ALVIM, Agostinho. Da inexecução das obrigações e suas consequências. São Paulo:
} 
Revista Eletrônica de Direito Processual - REDP.

Rio de Janeiro. Ano 13. Volume 20. Número 3. Setembro a Dezembro de 2019

Periódico Quadrimestral da Pós-Graduação Stricto Sensu em Direito Processual da UERJ

Patrono: José Carlos Barbosa Moreira (in mem.). ISSN 1982-7636. pp. 01-19

www.redp.uerj.br

fortuito, a lei não incidirá diretamente sobre o fato, resolvendo a relação obrigacional automaticamente, ipso iure, mas conferir-se-á ao credor o direito potestativo de resolver a relação obrigacional extrajudicialmente, ou promover a execução pelo equivalente.

Podem, ainda, os contratantes manter a alocação do risco estabelecida pelo legislador e apenas alterar os efeitos de sua verificação, a exemplo do que ocorre quando as partes incluem vícios redibitórios no suporte fático da cláusula; nesse caso, o comprador não precisará ajuizar a ação redibitória para redibir o contrato, e poderá fazê-lo extrajudicialmente uma vez constatado o vício oculto que torne a coisa imprópria ao uso a que se destina, nos termos do art. 441 do Código Civil.

A rigor, admitir a gestão mais ampla dos riscos contratuais por meio da cláusula resolutiva expressa potencializa sua vocação de instituto voltado à autotutela, ${ }^{24}$ função essa já reconhecida por Darcy Bessone, ao afirmar que a cláusula resolutiva expressa derroga, por vontade das partes manifestada no contrato, o princípio segundo o qual a ninguém é lícito fazer justiça pelas próprias mãos. ${ }^{25}$

No âmbito da cláusula resolutiva expressa, o poder de autotutela nasce a partir do exercício da autonomia privada, a evidenciar o seu papel instrumental em relação à autotutela: a autonomia privada predispõe acerca das condições necessárias ao nascimento do específico poder de autodefesa, cujo exercício depende da efetiva realização do fato lesivo.

Nesse sentido, afirma Lina Bigliazzi Geri que, a rigor, o direito de resolver a relação contratual:

[...] non deriva automaticamente dalla clausola negoziale in tal senso predisposta, rappresentando la stipulazione di questa il semplice presupposto dell'efficacia immediata della dischiarazione di 'volersene valere', nel que consiste l'esercizio del (nuovo) diritto. La fattispecie è diversa da quella originaria e contiene, ora, il diritto del creditore a realizzare l'effetto che rappresenta il contenuto del diritto stesso. La dichiarazione del creditore si configura, dunque, come l'espressione non già del diritto di autonomia, bensì di quello (specifico) di autotutela. ${ }^{26}$

\footnotetext{
Saraiva, 1965. p. 320). Em sentido contrário, Arnoldo Medeiros da Fonseca não exige a indicação de cada um dos riscos assumidos pelo contratante: "Só os riscos decorrentes de casos fortuitos que foram ou podiam ser previstos na data da obrigação consideram-se assumidos pelo devedor, no caso de dúvida, pois as exceções devem ser interpretadas restritivamente" (FONSECA, Arnoldo Medeiros da. Caso fortuito e teoria da imprevisão. 3. ed. Rio de Janeiro: Forense, 1958. p. 181, grifos no original).

${ }^{24}$ No direito estrangeiro, também salienta a relevância da cláusula resolutiva expressa como instrumento de autotutela, ROSSETTI, Marco. La risoluzione per inadempimento. Milano: Giuffrè, 2012, p. 381.

${ }^{25}$ BESSONE, Darcy. Do Contrato. Rio de Janeiro: Forense, 1960, p. 324.

${ }^{26}$ GERI, Lina Bigliazzi. Profili sistematici dell'autotutela privata: introduzione. t. I, Milano, Giuffrè, 1971, p. 85.
} 
Revista Eletrônica de Direito Processual - REDP.

Rio de Janeiro. Ano 13. Volume 20. Número 3. Setembro a Dezembro de 2019

Periódico Quadrimestral da Pós-Graduação Stricto Sensu em Direito Processual da UERJ

Patrono: José Carlos Barbosa Moreira (in mem.). ISSN 1982-7636. pp. 01-19

www.redp.uerj.br

Não se defende, aqui, a expansão dos instrumentos resolutórios, o que resultaria em

admitir a autotutela sem previsão legal. Afirma-se, apenas, a possibilidade de, por meio de leitura funcional da cláusula resolutiva expressa, dilatar seu suporte fático para também abarcar a gestão de outros riscos, além do inadimplemento absoluto. A incorporação à cláusula de determinados riscos assumidos expressamente pelos contratantes ou a eles já alocados pela teoria do risco estende a autotutela para situações funcionalmente equivalentes àquela já admitida em lei.

De todo modo, para que a autotutela seja efetivamente franqueada ao credor, imprescindível que a cláusula resolutiva expressa observe o chamado "requisito de especificidade". Significa que não basta que os contratantes mencionem que o descumprimento de qualquer obrigação autorizará a resolução extrajudicial, ou que a verificação de qualquer caso fortuito ou vício redibitório produzirá o mesmo efeito. Cláusulas assim redigidas são consideradas cláusulas de mero estilo, sem valor resolutório. ${ }^{27}$ Impõe-se, com efeito, que da cláusula conste expressamente as obrigações reputadas essenciais, ou as hipóteses de caso fortuito alocadas ao devedor, assim como os vícios ocultos capazes de comprometer irremediavelmente a utilidade da prestação cujo inadimplemento, superveniência, ou verificação ensejará a resolução extrajudicial.

A exigência se justifica. No que tange, por exemplo, às obrigações contratuais, a cláusula resolutiva expressa afasta o regime legal da cláusula resolutiva tácita, que requer a atuação do Poder Judiciário para a resolução da relação obrigacional. Com efeito, inexistindo a cláusula, se entender o credor que o devedor descumpriu obrigação essencial, incorrendo em inadimplemento absoluto, caberá a ele, credor, ajuizar ação e provar a essencialidade da obrigação e a consequente configuração do inadimplemento absoluto, de modo a permitir que o magistrado resolva a relação. A avaliação acerca da essencialidade da obrigação descumprida é levada a cabo, portanto, a posteriori, observado o contraditório e a ampla defesa.

De outro lado, por meio da cláusula resolutiva expressa, os contratantes avaliam, ex ante, conjuntamente, a essencialidade das obrigações imputadas ao devedor, e incluem no seu

\footnotetext{
27 BESSONE, Darcy. Do contrato. Rio de Janeiro: Forense, 1960. p. 325. Reconhece-se, todavia, que a jurisprudência nacional não se ocupa do requisito da especificidade e admite a validade de cláusulas genéricas, como o fez, por exemplo, o Tribunal de Justiça de Minas Gerais, que admitiu a resolução de contrato de distribuição do qual constou cláusula redigida nos seguintes termos: "Poderá em caso de inadimplemento de qualquer das cláusulas deste contrato, se não sanado em um prazo de 15 (quinze) dias do recebimento de notificação protocolada, rescindir o contrato, a parte prejudicada, fazendo jus a perdas e danos decorrentes do inadimplemento" (Tribunal de Justiça de Minas Gerais. AC 1.0024.06.244840-2/002. Relator: Des. Márcia De Paoli Balbino. Julgamento: 29.05.2009. Órgão Julgador: $17^{\text {a }}$ Câmara Cível).
} 
suporte fático aquelas reputadas, por ambas as partes, essenciais para o atendimento do interesse útil do credor. Ora, o devedor já sabe, de antemão, que obrigações, uma vez descumpridas, conduzirão ao inadimplemento absoluto, autorizando o credor a resolver extrajudicialmente a relação obrigacional. O exercício da autotutela com o consequente afastamento da intervenção judicial para a resolução decorre, em última instância, do fato de as próprias partes terem se antecipado à análise acerca da relevância de todas as obrigações e pactuado quais delas, uma vez descumpridas, ensejarão a configuração de inadimplemento absoluto.

Há, portanto, um ajuste bilateral acerca da essencialidade das obrigações, de modo que nada é imposto pelo credor arbitrária e unilateralmente. Se falta esse ajuste, se não é dado ao devedor saber, previamente, que obrigações o credor reputa essenciais para a consecução do resultado útil programado, as consequências da inexecução de qualquer delas devem ser discutidas em juízo, e o credor deverá provar o inadimplemento absoluto, a autorizar a resolução da relação obrigacional.

Já em relação ao risco de impossibilidade decorrente de certo fortuito expressamente assumido pelo devedor, a sua verificação, a rigor, configura inadimplemento absoluto, a atrair a disciplina específica da teoria do inadimplemento. Logo, aplicável, aqui, tudo o que se acabou de afirmou acima acerca do ajuste, ex ante, entre as partes, dos descumprimentos configuradores do inadimplemento absoluto e, consequentemente, autorizadores da resolução extrajudicial.

Por fim, no que tange aos vícios redibitórios, de regra, exige-se que a redibição se processe judicialmente em razão da necessidade de o juiz verificar se a alegação de perda de utilidade da prestação pelo credor é, de fato, procedente. Dessa forma, para que seja extrajudicial a resolução, é imprescindível que os contratantes indiquem, também anteriormente e de comum acordo na cláusula resolutiva expressa, em que circunstâncias a prestação não terá mais a utilidade necessária à promoção da função econômico-individual do contrato. ${ }^{28} \mathrm{O}$ vendedor, assim como os demais devedores nas hipóteses anteriores, participou da elaboração da cláusula e com ela concordou, tendo pleno conhecimento, desde a celebração do contrato, dos vícios que retiram da coisa toda a utilidade almejada pelo comprador.

\footnotetext{
${ }^{28}$ Não é necessário, portanto, que a prestação já não tenha qualquer utilidade em abstrato, mas apenas que o defeito lhe retire a idoneidade de promover o concreto escopo econômico do contrato. Nesse sentido, confira-se GAROFALO, Luigi. Garanzia per vizi e azione redibitoria nell'ordinamento italiano. Rivista di Diritto Civille, Padova, v. 47, p. 249, jan./fev. 2001.
} 
Revista Eletrônica de Direito Processual - REDP.

Rio de Janeiro. Ano 13. Volume 20. Número 3. Setembro a Dezembro de 2019

Periódico Quadrimestral da Pós-Graduação Stricto Sensu em Direito Processual da UERJ

Patrono: José Carlos Barbosa Moreira (in mem.). ISSN 1982-7636. pp. 01-19

www.redp.uerj.br

Concebida em tais bases, a cláusula resolutiva expressa proporciona aos

contratantes ambiente negocial mais seguro e previsível: permite-lhes preestabelecer, conjuntamente, em que situações a relação poderá ser resolvida por não ser capaz de promover os interesses concretamente perseguidos, e faculta à parte lesada livrar-se imediatamente da relação disfuncional, imprestável à finalidade a que se dirigia, sem que, para isso, necessite recorrer ao Estado-juiz, resolvendo a relação obrigacional de pleno direito, por meio do exercício da autotutela.

\section{Resolução extrajudicial da relação obrigacional: a secundarização da atuação do Poder}

\section{Judiciário}

Verificado o descumprimento da obrigação essencial inserida na cláusula resolutiva expressa, a configurar inadimplemento absoluto, advindo o evento fortuito ${ }^{29}$ ou presente o defeito nela previsto, cuidando-se de credor não inadimplente, ${ }^{30}$ confere-se-lhe o direito potestativo de escolher entre as possibilidades previstas no artigo 475 do Código Civil: "pedir a resolução do contrato, se não preferir exigir-lhe o cumprimento, cabendo, em qualquer dos casos, indenização por perdas e danos".

Importa sublinhar que o art. 475 não franqueia ao credor a escolha entre execução específica - como poderia parecer a partir da expressão "preferir exigir-lhe o cumprimento" -, e a resolução, mas entre a execução pelo equivalente e a resolução. ${ }^{31}$ Ora, caso se esteja,

\footnotetext{
${ }^{29}$ Não se incluiu a referência aos vícios redibitórios eventualmente inseridos na cláusula resolutiva expressa porque, neste caso, a cláusula pode apenas disciplinar os efeitos do risco já alocado pelo legislador, hipótese em que se produzem os efeitos específicos previstos em lei em relação a referido risco. Desse modo, previstos vícios redibitórios no suporte fático da cláusula, permite-se que o comprador resolva extrajudicialmente o contrato, não sendo necessário ajuizar ação redibitória, nos termos do artigo 441 do Código Civil. Neste caso, o pagamento de indenização por perdas e danos dependerá da boa-fé subjetiva do alienante, ou seja, do seu conhecimento a respeito do vício ou defeito, de acordo com o que determina o artigo 443. Nada impede, porém, que o alienante assuma todos os riscos relativos aos vícios redibitórios, hipótese em que deverá pagar a indenização cabível. Nesta situação, as partes não terão somente disciplinado os efeitos dos riscos previamente alocados pelo legislador, mas terão também procedido a uma nova alocação de riscos.

${ }^{30}$ Para análise detida dos requisitos necessários para que se confira o direito potestativo ao credor, seja consentido remeter a TERRA, Aline de Miranda Valverde. Cláusula resolutiva expressa. Belo Horizonte: Fórum, 2017. p. 97 et. seq.

${ }^{31}$ Araken de Assis, ao discorrer acerca dos limites à liberdade de escolha do credor, afirma, categoricamente: "[...] há limites práticos que condicionam a escolha. Por exemplo, o inadimplemento absoluto torna irrecuperável a prestação, e, portanto, inútil ao credor trilhar o caminho da demanda de cumprimento, exceto para pedir uma prestação pecuniária equivalente" (ASSIS, Araken; ANDRADE, Ronaldo Alves de; ALVES, Francisco Glauber Pessoa. Comentários ao Código Civil brasileiro. Rio de Janeiro: Forense, 2007. v. 5. p. 611). Confira-se, no mesmo sentido, Ruy Rosado de Aguiar Júnior: "Se a prestação se tornou impossível por culpa do devedor, o credor pode optar entre pedir a resolução do contrato ou o adimplemento, pelo equivalente (art. 389 do Código Civil). [...] Se o incumprimento definitivo, por perda do interesse na prestação, resultar de culpa do devedor, o credor não exigirá a execução em espécie, que já não lhe traz nenhuma utilidade, mas poderá optar entre manter o contrato e obter o
} 
Revista Eletrônica de Direito Processual - REDP.

Rio de Janeiro. Ano 13. Volume 20. Número 3. Setembro a Dezembro de 2019

Periódico Quadrimestral da Pós-Graduação Stricto Sensu em Direito Processual da UERJ

Patrono: José Carlos Barbosa Moreira (in mem.). ISSN 1982-7636. pp. 01-19

www.redp.uerj.br

verdadeiramente, diante de inadimplemento absoluto, decorrente de impossibilidade ou de inutilidade da prestação, não há como se admitir a execução específica: como executar o que se impossibilitou para o devedor, ou para que exigir o que se tornou inútil para o credor? A execução específica é remédio conferido ao credor somente em caso de mora, em que o devedor ainda pode cumprir utilmente a prestação devida. Em definitivo, diante de inadimplemento absoluto, ao credor resta apenas resolver o contrato ou demandar o cumprimento da prestação pelo equivalente. ${ }^{32}$ Evidentemente, não se afasta a possibilidade de o credor, constatada a inexecução do devedor, pleitear a execução específica; no entanto, se o fizer, a inexecução se qualificará como mora, não já como inadimplemento absoluto, a afastar a própria possibilidade de execução da cláusula resolutiva expressa.

O exercício do direito potestativo pelo credor deve ser efetivado por meio de comunicação ao devedor da opção selecionada. Não há, na lei, previsão de prazo dentro do qual o credor deva manifestar sua vontade. ${ }^{33}$ Por se cuidar de direito potestativo convencional, as próprias partes podem ajustar o prazo decadencial para seu exercício. Inexistindo a estipulação contratual, como o surgimento da opção em favor do credor entre resolver a relação obrigacional ou executar a prestação pelo equivalente faz nascer, concomitantemente, um estado de sujeição para o devedor, admite-se a possibilidade de o próprio devedor fixar ao titular prazo razoável para o exercício da escolha, a fim de acabar com as incertezas sobre o futuro da relação contratual.

De todo modo, mesmo diante da omissão legislativa e contratual, não se pode perder de vista que o direito de crédito está sujeito à prescrição, a partir da qual o credor não mais poderá exigir o equivalente da prestação e tampouco pleitear a restituição do que eventualmente já houver prestado, se optar pela resolução do contrato. Não se trata, evidentemente, de sustentar a prescrição do direito potestativo. Trata-se de reconhecer que, embora o credor continue a ter o direito de resolver o contrato a despeito da prescrição da pretensão do direito de crédito, os

equivalente (art. 236 do Código Civil) ou requerer a resolução (art. 475 do Código Civil), sempre com perdas e danos" (AGUIAR JÚNIOR, Ruy Rosado. Comentários ao novo Código Civil: da extinção do contrato. Coordenação de Sálvio de Figueiredo Teixeira. Rio de Janeiro: Forense, 2011. v. 6, t. 2. p. 388-389).

${ }^{32}$ Sobre execução pelo equivalente, seja consentido remeter a TERRA, Aline de Miranda Valverde. Execução pelo equivalente como alternativa à resolução: repercussões sobre a responsabilidade civil. Revista Brasileira de Direito Civil-RBDCivil, Belo Horizonte, v. 18, p. 49-73, out./dez. 2018.

${ }^{33}$ Tratando-se de resolução por vícios redibitórios, o prazo decadencial para resolver a relação obrigacional é de 30 dias, se a coisa for móvel, e de 1 ano, se imóvel, contado da entrega efetiva; se o adquirente já estava na posse, o prazo conta-se da alienação, reduzido à metade, conforme determina o art. 445 do Código Civil. Por outro lado, determina o parágrafo primeiro do mesmo dispositivo: “Quando o vício, por sua natureza, só puder ser conhecido mais tarde, o prazo contar-se-á do momento em que dele tiver ciência, até o prazo máximo de cento e oitenta dias, em se tratando de bens móveis; e de um ano, para os imóveis". 
Revista Eletrônica de Direito Processual - REDP.

Rio de Janeiro. Ano 13. Volume 20. Número 3. Setembro a Dezembro de 2019

Periódico Quadrimestral da Pós-Graduação Stricto Sensu em Direito Processual da UERJ

Patrono: José Carlos Barbosa Moreira (in mem.). ISSN 1982-7636. pp. 01-19

www.redp.uerj.br

direitos subjetivos provenientes da resolução encontram-se desprovidos de exigibilidade, já que alcançados pela prescrição.

A opção do credor pela resolução ou pela execução pelo equivalente dependerá dos efeitos que pretende sejam produzidos. A execução pelo equivalente, ao contrário da resolução, conserva a relação obrigacional, que não se desfaz. Permite-se ao credor manter o vínculo obrigacional, que ainda lhe interessa - apesar de a prestação devida ter se impossibilitado ou se tornado inútil -, seja porque deseja executar a prestação que lhe incumbe, ou porque já a executou e não quer recebê-la de volta. ${ }^{34}$

Outra distinção relevante reside no montante indenizatório a que o credor fará jus. A responsabilidade pelo equivalente se funda no interesse positivo, ou "interesse de cumprimento", ao contrário de perdas e danos devidos por ocasião da resolução, que se restringem ao interesse negativo, como se abordará adiante. Significa, portanto, que na execução pelo equivalente, além de pleitear a substituição da coisa que lhe é devida pelo seu equivalente pecuniário, receberá o credor indenização suficiente a colocá-lo na mesma situação em que estaria caso o contrato tivesse sido adimplido na forma, no dia e no lugar ajustados.

Essa diferença entre os montantes indenizatórios decorre, na realidade, da própria diversidade de escopo dos dois instrumentos de tutela: enquanto na resolução o credor pretende se exonerar da obrigação a que se comprometeu e reposicionar seu patrimônio no estado em que se encontraria se não tivesse celebrado o contrato, na execução pelo equivalente o credor busca se colocar na situação de vantagem em que estaria se tivesse havido o adimplemento.

E a indenização devida em ambos os casos segue a mesma lógica, como se extrai do exemplo formulado por Jorge Leite Areias Ribeiro de Faria:

Suponhamos que $A$, proprietário de um cavalo, que vale 600 , o troca pelo automóvel de $B$, que vale 500. $A$ venderia o automóvel a $C$ por 800 e, se não tivesse celebrado o contrato, teria tido a oportunidade de vender o cavalo a $D$ por 700. Entretanto, antes da entrega do carro, $B$ tem um acidente e o carro fica totalmente destruído. $B$ teve culpa no acidente. Atente-se agora na diferença de resultados práticos, consoante se trilha uma ou outra via. Se o credor optasse pelo direito à indenização, receberia 800 , mas entregaria o cavalo, de valor igual a 600 . Se ele optasse pela resolução, não faria eventualmente a entrega do cavalo (assim, se ainda não tivesse realizado a

\footnotetext{
${ }^{34}$ Observe-se, todavia, que, neste caso, o credor até poderia optar pela resolução, exigindo a devolução do que prestou pelo equivalente, não já in natura, como se exporá no item 5.2, infra.
} 
Revista Eletrônica de Direito Processual - REDP.

Rio de Janeiro. Ano 13. Volume 20. Número 3. Setembro a Dezembro de 2019

Periódico Quadrimestral da Pós-Graduação Stricto Sensu em Direito Processual da UERJ

Patrono: José Carlos Barbosa Moreira (in mem.). ISSN 1982-7636. pp. 01-19

www.redp.uerj.br

contraprestação) e receberia 100 (o lucro que deixou de obter pela vinculação ao contrato resolvido). ${ }^{35}$

Havendo cláusula resolutiva expressa, há de se considerar, ainda, que a opção pela resolução confere ao credor solução muito mais célere do que a execução pelo equivalente, visto que tudo se passa extrajudicialmente, sem necessidade de intervenção judicial, bastando que o credor realize uma declaração receptícia de vontade. Este é, precisamente, o efeito precípuo da cláusula resolutiva expressa, que a torna infinitamente mais atrativa do que a cláusula resolutiva tácita: a resolução extrajudicial da relação obrigacional, implementada por simples declaração do credor.

A resolução extrajudicial vem, com efeito, ao encontro da necessidade, cada vez mais premente, de assegurar certeza e celeridade às relações contratuais. Por encerrar mecanismo legítimo de autotutela dos interesses do credor, a resolução extrajudicial favorece o tráfico de bens e, consequentemente, a circulação de riquezas, eximindo-o de se submeter à demorada e custosa atuação judicial para obter uma resposta a respeito do rompimento do vínculo obrigacional.

A resolução extrajudicial ajuda a instrumentalizar, nesse contexto, o princípio da operosidade, cunhado por Paulo Cezar Pinheiro Carneiro para expressar, no bojo do movimento de acesso à justiça, o dever de todas as pessoas que participam da atividade judicial ou extrajudicial de "atuar da forma mais produtiva e laboriosa possível para assegurar o efetivo acesso à justiça", sendo indispensável que a atuação se dê pelos trilhos da ética, na busca da melhor produtividade possível, por meio de técnicas adequadas aos fins pretendidos. ${ }^{36}$

Assim, em sistemas em que a resolução se opera por mera declaração do credor, a secundarização do papel do juiz na apreciação da cláusula pode ser atenuada por iniciativa do devedor. ${ }^{37} \mathrm{Se}$ inevitável o litígio, a intervenção judicial será meramente fiscalizadora da legitimidade do exercício da autonomia privada na elaboração da cláusula resolutiva e do efetivo preenchimento dos pressupostos autorizadores da resolução. De todo modo, a atuação

\footnotetext{
${ }^{35}$ FARIA, Jorge Leite Areias Ribeiro de. Direito das obrigações. Coimbra: Almedina, 2001. v. 2. p. 428-429.

${ }^{36}$ CARNEIRO, Paulo Cezar Pinheiro. Acesso à justiça: juizados especiais cíveis e ação civil pública: uma nova sistematização da teoria geral do processo. 2. ed. rev. atual. Rio de Janeiro: Forense, 2007. pp 71-88.

${ }^{37}$ PROENÇA, José Carlos Brandão. A resolução do contrato no Direito Civil: do enquadramento e do regime. Coimbra: Coimbra Editora, 2006. p.113.
} 
Revista Eletrônica de Direito Processual - REDP.

Rio de Janeiro. Ano 13. Volume 20. Número 3. Setembro a Dezembro de 2019

Periódico Quadrimestral da Pós-Graduação Stricto Sensu em Direito Processual da UERJ

Patrono: José Carlos Barbosa Moreira (in mem.). ISSN 1982-7636. pp. 01-19

www.redp.uerj.br

judicial será a posteriori $^{38}$ e, verificada a presença dos pressupostos resolutivos, a sentença será meramente declaratória, a reconhecer a resolução ope voluntatis. ${ }^{39}$

Os Tribunais atentos à melhor técnica têm cuidado, em boa parte, de prestigiar a autonomia privada dos contratantes, de ser deferente à autonomia privada, reconhecendo que, presente cláusula resolutiva expressa, confere-se ao credor autotutela, e a resolução se processa extrajudicialmente. ${ }^{40}$ No entanto, há decisões que, a despeito da presença de cláusula resolutiva expressa, exigem a prévia manifestação judicial para que se opere a resolução, o que é bastante recorrente no âmbito de ação de reintegração de posse do imóvel objeto de promessas de compra e venda. ${ }^{41}$

Ao que parece, com as devidas vênias, há um erro de perspectiva nesses julgados. Embora se reconheça que semelhantes contratações envolvam, muitas vezes, especial interesse - aquisição da casa própria -, revestindo-se de relevância social justificadora da intervenção protetiva do Estado, é preciso atentar para o fato de que o Decreto-Lei $n^{\circ} 745 / 69$ e a Lei $n^{\circ}$ 6.766/79 já flexibilizaram o rigor da disciplina do Código Civil, exigindo notificação do promitente comprador para sua constituição em mora, mesmo que haja termo de adimplemento contratualmente ajustado ou cláusula resolutiva expressa. No entanto, essa é a única peculiaridade que referidas leis impõem, nada mais; após a notificação, tudo deve se passar consoante a especial disciplina da cláusula resolutiva expressa: resolve-se a relação obrigacional extrajudicialmente.

Ademais, eventual necessidade de ajuizamento de ação de reintegração de posse não torna necessário que o credor também recorra ao Judiciário para obter a resolução do contrato, tanto mais no âmbito de relações paritárias: resolve-se o contrato extrajudicialmente e ajuíza-se a ação para a reintegração. Conquanto, não raro, se faça necessário recorrer ao

\footnotetext{
${ }^{38}$ BESSONE, Darcy. Do contrato. Rio de Janeiro: Forense, 1960. p. 325.

${ }^{39}$ AGUIAR JÚNIOR, Ruy Rosado. Comentários ao novo Código Civil: da extinção do contrato. Coordenação de Sálvio de Figueiredo Teixeira. Rio de Janeiro: Forense, 2011. v. 6, t. 2. p. 494.

${ }^{40}$ Confira-se, por exemplo: Tribunal de Justiça do Rio de Janeiro. AC 0035062-45.2013.8.19.0001. Relator: Des. Sérgio Wajzenberg. Julgamento: 27.04.2016. Órgão Julgador: $24^{a}$ Câmara Cível; Tribunal de Justiça de São Paulo. AC 0021370-86.2009.8.26.0562. Relator: Des. Gilson Delgado Miranda. Julgamento: 24.02.2015. Órgão Julgador: 28 ${ }^{\mathrm{a}}$ Câmara de Direito Privado; Tribunal de Justiça do Distrito Federal e dos Territórios. AC 20110111863536. Relator: Des. Arnoldo Caminho de Assis. Julgamento: 30.01.2013. Órgão Julgador: $4^{\mathrm{a}}$ Turma Cível; Tribunal de Justiça do Paraná. AC 1.187.541-1. Relator: Des. Fábio Haick Dalla Vecchia. Julgamento: 22.07.2014. Órgão Julgador: $7^{a}$ Câmara Cível.

${ }^{41}$ Superior Tribunal de Justiça. Resp. 620.787/SP. Relator: Min. Luis Felipe Salomão. Julgamento: 28.04.2009. Órgão Julgador: $4^{\mathrm{a}}$ Turma; Tribunal de Justiça de Minas Gerais. AI 1.0024.11.026503-0/001. Rel. Des. José Affonso da Costa Côrtes. Órgão Julgador: $15^{a}$ Câmara Cível. Julgamento: 19.05.2011; Tribunal de Justiça de Minas Gerais. AI 1.0702.11.025067-8/001. Relator: Des. José Antônio Braga. Julgamento: 07.06.2011. Órgão Julgador: $9^{a}$ Câmara Cível.
} 
Revista Eletrônica de Direito Processual - REDP.

Rio de Janeiro. Ano 13. Volume 20. Número 3. Setembro a Dezembro de 2019

Periódico Quadrimestral da Pós-Graduação Stricto Sensu em Direito Processual da UERJ

Patrono: José Carlos Barbosa Moreira (in mem.). ISSN 1982-7636. pp. 01-19

www.redp.uerj.br

Judiciário para que se produzam os efeitos materiais da resolução, isso não significa que a própria resolução tenha que se processar judicialmente. Cuida-se de problemas distintos, a serem resolvidos em esferas distintas.

Em boa hora, ante a resistência à efetividade da cláusula resolutiva expressa aposta em promessas de compra e venda, editou-se a Lei n ${ }^{\circ} 13.097$, de 19 de janeiro de 2015, cujo artigo 62 altera o artigo $1^{\circ}$ do Decreto-Lei $n^{\circ} 745 / 69$, que passou a vigorar com a seguinte redação:

Art. $1^{\circ}$ Nos contratos a que se refere o art. 22 do Decreto-Lei $\mathrm{n}^{\circ}$ 58, de 10 de dezembro de 1937, ainda que não tenham sido registrados junto ao Cartório de Registro de Imóveis competente, o inadimplemento absoluto do promissário comprador só se caracterizará se, interpelado por via judicial ou por intermédio de cartório de Registro de Títulos e Documentos, deixar de purgar a mora, no prazo de 15 (quinze) dias contados do recebimento da interpelação.

Parágrafo único. Nos contratos nos quais conste cláusula resolutiva expressa, a resolução por inadimplemento do promissário comprador se operará de pleno direito (art. 474 do Código Civil), desde que decorrido o prazo previsto na interpelação referida no caput, sem purga da mora.

A lei, a toda evidência, pretendeu corrigir o desvio de percurso da jurisprudência, reafirmando a produção do efeito perseguido pelas partes com a inserção de cláusula resolutiva expressa no contrato, mesmo em promessa de compra e venda: a resolução extrajudicial da relação obrigacional. Resta, agora, aguardar que os aplicadores do direito acolham a disposição legal e passem, efetivamente, a aplicar a disciplina resolutiva em sua inteireza, prestigiando a autonomia privada sempre que legitimamente exercida. ${ }^{42}$

\footnotetext{
${ }^{42}$ Nessa direção, confira-se a decisão do Tribunal de Justiça de São Paulo, em cuja ementa se lê: “Tutela antecipada - Compromisso de compra e venda - Decisão que deferiu liminar para reintegração dos autores promitentes vendedores na posse do imóvel - Inconformismo dos réus, que imputam aos autores a culpa pelo inadimplemento, bem como sustentam a necessidade de prévia rescisão do contrato por determinação judicial - Descabimento - art. $1^{\circ}$ do Decreto-Lei $n^{\circ} 745$ de 7 de agosto de 1969 teve sua redação recentemente alterada pela Lei $\mathrm{n}^{\circ} 13.097$ de 19 de janeiro de 2015, dando eficácia à cláusula resolutória expressa quando o promissário comprador é interpelado e deixa de purgar a mora no prazo de 15 dias contados do recebimento desta - Ainda que a notificação previamente encaminhada pelos autores não tenha sido feita pela via judicial ou por intermédio de cartório de títulos, a citação para o feito de origem faz as vezes de interpelação judicial - Incontroverso o inadimplemento e não havendo notícia de purgação da mora, realmente não há óbice ao deferimento da antecipação de tutela, ante a eficácia da cláusula resolutória (...)" (Tribunal de Justiça de São Paulo. AI 2079575-67.2016.8.26.0000, Relator: Des. Rui Cascaldi. Julgamento: 06.07.2016. Órgão Julgador: $1^{\text {a }}$ Câmara de Direito Privado).
} 


\section{Conclusão}

O reconhecimento de que a tutela efetiva e tempestiva dos direitos, pilar principal do movimento de acesso à justiça, não constitui monopólio do Poder Judiciário tem estimulado, entre nós, o fenômeno da desjudicialização, sem que daí decorra, a priori, uma violação ao princípio da inafastabilidade da jurisdição.

Nesse cenário, a cláusula resolutiva expressa desponta como instrumento privilegiado de autotutela, e contribui para a criação de ambiente negocial mais seguro e previsível para os contratantes, uma vez que lhes permite preestabelecer, livre e conjuntamente, em que situações a relação poderá ser resolvida por não ser capaz de promover os interesses concretamente perseguidos pelo credor, e faculta à parte lesada se livrar imediatamente da relação disfuncional, imprestável à finalidade a que se dirige, sem que, para isso, tenha de se submeter às dificuldades de um processo judicial.

Ao permitir que o credor resolva, ele próprio, a relação obrigacional, a cláusula resolutiva expressa secundariza o papel do Estado-juiz na extinção do vínculo jurídico, que será chamado a atuar a posteriori e, de regra, por iniciativa do devedor.

\section{REFERÊNCIAS}

AGUIAR JÚNIOR, Ruy Rosado. Comentários ao novo Código Civil: da extinção do contrato. Coordenação de Sálvio de Figueiredo Teixeira. Rio de Janeiro: Forense, 2011. v. 6, t. 2. ALPA, Guido. Manuale di diritto privato. 8. ed., Padova: CEDAM, 2013.

ALVIM, Agostinho. Da inexecução das obrigações e suas consequências. São Paulo: Saraiva, 1965.

ASSIS, Araken; ANDRADE, Ronaldo Alves de; ALVES, Francisco Glauber Pessoa. Comentários ao Código Civil brasileiro. Rio de Janeiro: Forense, 2007. v. 5.

BARBOSA MOREIRA, José Carlos. O problema da duração dos processos: premissas para uma discussão séria. In: Temas de direito processual, nona série. São Paulo: Saraiva, 2007.

. Tutela de urgência e efetividade do direito. In: Temas de direito processual, oitava série. São Paulo: Saraiva, 2004.

BESSONE, Darcy. Do Contrato. Rio de Janeiro: Forense, 1960. 
Revista Eletrônica de Direito Processual - REDP.

Rio de Janeiro. Ano 13. Volume 20. Número 3. Setembro a Dezembro de 2019

Periódico Quadrimestral da Pós-Graduação Stricto Sensu em Direito Processual da UERJ

Patrono: José Carlos Barbosa Moreira (in mem.). ISSN 1982-7636. pp. 01-19

www.redp.uerj.br

CARNEIRO, Paulo Cezar Pinheiro. Acesso à justiça: juizados especiais cíveis e ação civil pública: uma nova sistematização da teoria geral do processo. 2. ed. rev. atual. Rio de Janeiro: Forense, 2007.

CAVALIERI FILHO, Sérgio. Programa de responsabilidade civil. 6. ed. rev. aum. e atual. São Paulo: Malheiros, 2006.

FARIA, Jorge Leite Areias Ribeiro de. Direito das obrigações. Coimbra: Almedina, 2001. v. 2.

FONSECA, Arnoldo Medeiros da. Caso fortuito e teoria da imprevisão. 3. ed. Rio de Janeiro: Forense, 1958.

GAROFALO, Luigi. Garanzia per vizi e azione redibitoria nell'ordinamento italiano. Rivista di Diritto Civille, Padova, v. 47, p. 249, jan./fev. 2001.

GERI, Lina Bigliazzi. Profili sistematici dell'autotutela privata: introduzione. t. I, Milano, Giuffrè, 1971.

GRECO, Leonardo. Garantias fundamentais do processo: o processo justo. In: Estudos de direito processual. Campos dos Goytacazes: Ed. Faculdade de Direito de Campos, 2005.

IBARGUREN, Carlos. Apuntes de derecho romano: obligaciones. Buenos Aires: Virtus, 1932.

PEREIRA, Caio Mário da Silva. Responsabilidade civil. 10. ed. rev. e atual. Rio de Janeiro: GZ, 2012.

PERLINGIERI, Pietro. Manuale di diritto civile. Napoli: ESI, 2005.

PONTES DE MIRANDA, Francisco Cavalcanti. Tratado de Direito Privado. t. 2, 2. ed. Rio de Janeiro: Editor Borsoi, 1954.

PROENÇA, José Carlos Brandão. A resolução do contrato no direito civil: do enquadramento e do regime. Coimbra: Coimbra Editora, 2006.

PROTO PISANI, Andrea. Verso la residualità del processo a cognizione piena? In: Studi in onore di Carmine Punzi. Torino: G. Giappichelli Editore, 2008. v. 1.

ROSSETTI, Marco. La risoluzione per inadempimento. Milano: Giuffrè, 2012.

SALLES, Raquel Bellini de Oliveira. Autotutela pelo inadimplemento nas relações contratuais. Tese (Doutorado em Direito Civil) - Faculdade de Direito, Universidade do Estado do Rio de Janeiro, Rio de Janeiro, 2011.

SCHENK, Leonardo Faria. Cognição sumária: limites impostos pelo contraditório no processo civil. São Paulo: Saraiva, 2013. 
Revista Eletrônica de Direito Processual - REDP.

Rio de Janeiro. Ano 13. Volume 20. Número 3. Setembro a Dezembro de 2019

Periódico Quadrimestral da Pós-Graduação Stricto Sensu em Direito Processual da UERJ

Patrono: José Carlos Barbosa Moreira (in mem.). ISSN 1982-7636. pp. 01-19

www.redp.uerj.br

TEPEDINO, Gustavo; BARBOZA, Heloisa Helena; BODIN DE MORAES, Maria Celina.

Código Civil interpretado conforme a Constituição da República. 2. ed. rev. e atual. Rio de Janeiro: Renovar, 2007. v. 1.

TERRA, Aline de Miranda Valverde. Cláusula resolutiva expressa. Belo Horizonte: Fórum, 2017.

. Execução pelo equivalente como alternativa à resolução: repercussões sobre a responsabilidade civil. Revista Brasileira de Direito Civil - RBDCivil, Belo Horizonte, v. 18, p. 49-73, out./dez. 2018.

WATANABE, Kazuo. Tutela antecipada e tutela específica das obrigações de fazer e não fazer (art. 273 e 461 do CPC). In: TEIXEIRA, Sálvio de Figueiredo. Reforma do código de processo civil. São Paulo: Saraiva, 1996. 